McGowan (2018)

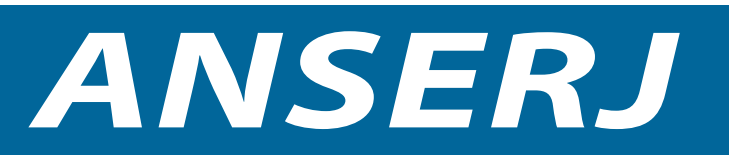

Vol. 9 , No. 2

Autumn / Automne 2018

pp. $5-22$

Canadian Journal of Nonprofit and Social Economy Research

Revue canadienne de recherche sur les OBSL et l'économie social

\title{
An Innovative Opportunity? Social Innovation, Entrepreneurship, and the Pedagogical Possibilities for Indigenous Learners
}

\author{
Katharine McGowan \\ Bissett School of Business, Mount Royal University
}

\begin{abstract}
The need to indigenize curriculum in Canada is pressing. Education, however, is fraught and complex. Questions have been asked about the accessibility and applicability of traditional class-based educational paradigms and subject matter. Based on the limited courses currently on offer in Canada, the emergent social-innovation pedagogy seems to bear several points of sympathy or commonality with Indigenous pedagogies, including emphasis on experiential learning, reflection, and collaborative work. Indigenous pedagogies and ways of knowing cannot and should not be slotted into a Eurocentric educational paradigm. This article will begin to explore this possible pedagogical sympathy-an overlap between the two knowledge systems - with the support of a group of Indigenous business students interested in social innovation as a tool to help them build the resilience of their communities.
\end{abstract}

\section{RÉSUMÉ}

II existe au Canada un besoin pressant d'autochtoniser le curriculum. II n'est pourtant pas toujours simple et facile de modifier le système éducatif, même si certains ont déjà mis en doute l'accessibilité et la pertinence du cours didactique traditionnel. À cet égard, on peut remarquer plusieurs affinités-y compris un accent mis sur l'apprentissage, la réflexion et le travail de collaboration par l'expérience—entre les pédagogies autochtones et la pédagogie émergente d'innovation sociale, malgré le nombre limité de cours de ce type offerts au Canada actuellement. Les pédagogies et manières de savoir autochtones ne peuvent pas, et ne devraient pas, être insérées dans un paradigme eurocentrique. Cet article entame l'exploration des affinités entre les deux systèmes de savoir en consultant des étudiants en commerce autochtones intéressés par l'innovation sociale comme outil pouvant les aider à rendre leurs communautés plus résilientes.

KEYWORDS / MOTS CLÉS Indigenous business; Social innovation; Pedagogy: Indigenous higher education; Business education / Affaires autochtones; Innovation sociale; Pédagogie; Études avancées autochtones; Éducation en commerce 


\section{McGowan (2018)}

\section{INTRODUCTION}

How can higher education support Indigenous communities' quests for continued and greater cultural, economic, and national resilience? The Truth and Reconciliation Commission's (TRC, 2015) calls to action are clear that higher education (as part of the education system) has a significant role to play in this imperative, as the calls include closing the funding and achievement gaps at all grade levels (calls 7, 8, and 11), supporting traditional language (calls 14 and 16), empowering parents and communities to be more involved in their children's education (call 10), and using education and academic research as tools for reconciliation itself (calls 62 through 65). The assertion by David Barnard (2015) of Universities Canada that the TRC has insisted that educational institutions must both work with Indigenous communities and be leaders in the wider effort towards reconciliation reflects this need. While efforts to increase Indigenous enrollment predate the TRC (Pidgeon, Archibald, \& Hawkey, 2014), in this post-TRC environment, Canadian educational institutions must also address the concerns expressed by existing Indigenous students who have equated traditional academic success with cultural assimilation and the loss of identity (Brayboy, 2005; Castagno \& Brayboy, 2008; Gallop \& Bastien, 2016; Hare \& Pidgeon, 2011; Neganagwedgin, 2001).

How can universities offer empowering education that does not replicate colonial structures and assumptions? This includes building mutually comprehensible pedagogy and research —referred to by Marie Battiste (2013) as a "trans-systemic bridge" (p. 100) -between Indigenous and non-Indigenous educational practices. Battiste (2013) described a space as spanning two distinct knowledge systems (hence they are not hierarchically ranked but horizontally spanned).

Bringing two diverse knowledge systems together needs some consideration of the assumptions underlying each foundation and where the points of inclusion or merging might seem advisable. The need then becomes one of developing 'trans-systemic' analyses and methods - that is, reaching beyond the two distinct systems of knowledge to create fair and just educational systems and experiences so that all students can benefit from their education in multiple ways. (p. 103)

Some of the origins of knowledge, their underlying philosophies and values, should be considered when comparing Indigenous and social innovation education to see if there is a potentially strong foundation for this bridge. This is an especially important journey for non-Indigenous/settler academics and instructors, who need to reflect and re-evaluate their practices and origins of expertise to decolonize their institutions.

\section{Research question}

This article explores the emerging social innovation educational approaches and the belief that a "social innovation education should encompass tools and methods that support the design of high impact solutions" (Russo \& Miller, 2013, p. 175) in the context of looking for a space with sympathetic aims with Indigenous pedagogies. Indeed, pedagogical projects have explored - with success - this pairing (Conrad, 2015); as a rough form of replication and expansion, could it extend to an entire pedagogical project, what Diane Conrad (2015) called "new paradigm thinking" (p.12)? This is meant as a reflection and an early exploration under ideal circumstances, as the precursor for a future, more contextual collaboration with Indigenous educators and pedagogical experts. Before building a trans-systemic bridge, it must be established to be on sure footing - are social innovation educators ready to take a fulsome role in reconciliation? 


\section{McGowan (2018)}

\section{Figure 1: Indigenous and social innovation pedagogical practices, imagined}

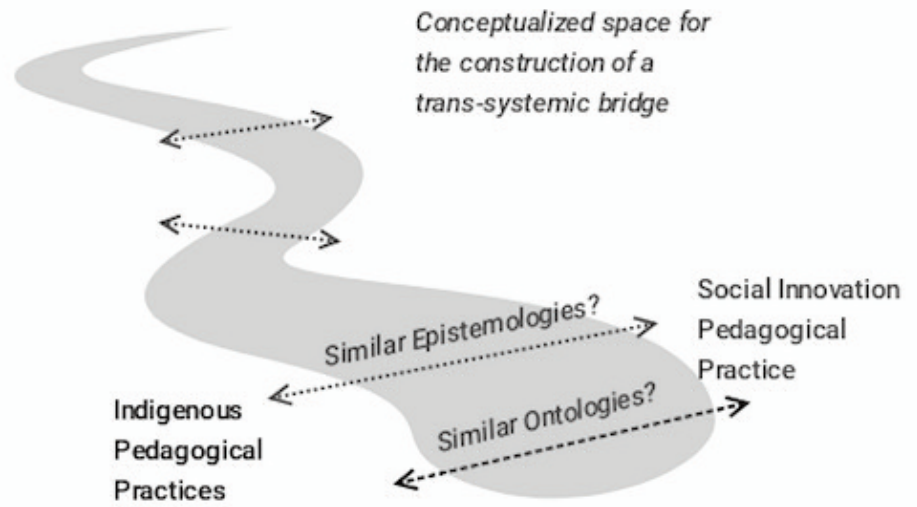

While the focus here is primarily ontological, the underlying epistemological pillars for both pedagogical streams may ultimately be more important in building a strong trans-systemic bridge: similar experiences with different theoretical drives, rationale, or worldview cannot be assumed to be equally aligned. By examining current wise practices on both shores (as conceptualized in Figure 1) and triangulating that with students' experiences and observations, it may be possible to begin identifying places to build that elusive trans-systemic bridge.

\section{Study rationale: Indigenous Innovation Summit}

Indigenous peoples in Canada have suffered-and continue to suffer-the traumas of colonization (Hurley \& Wherrett, 1999; TRC, 2015). Although the seriousness of these issues should not be understated, "what has received less attention is the degree of community cohesion that remains and the desire among many Indigenous peoples to rebuild their communities on a traditional and culturally-grounded foundation" (Anderson, Dana, \& Dana, 2006, p. 45). Rebuilding nations and communities "on their own terms for their own purposes," (Hindle, Anderson, Giberson, \& Kayseas, 2005, p. 1) has led many Indigenous community leaders to explore social innovation and social enterprise as a set of tools to build on and strengthen their resilience (Anderson et al., 2006; Anderson, Honig, \& Peredo, 2012; Hindle \& Moroz, 2010; Tapsell \& Woods, 2010; Volynets, 2015). Social innovation as an analytical tool has increasingly framed these efforts and those directed at self-determination (Alexiuk, 2013; McCarthy, Millen, Boyden, Alexiuk, Whitelaw, Viswanathan, Larkman, Rowe, \& Westley, 2014).

Narrowing this broad focus, the specific impetus for this study was the first Indigenous Innovation Summit in November 2015. It was summit organizers' contention that "Indigenous communities are innovative by nature" (National Association of Friendship Centres, 2016, p. 4); it was a lack of common language that kept Indigenous communities isolated from the wider social innovation conversation. The experience raised the question of if and how Indigenous educational and pedagogical concerns and social innovation thinking could come together in a deliberate way. Social innovation out of the classroom is not abnormal and is considered a valid platform for education (Conrad, 2015). This was imperative because the overlap between social innovation and Indigenous innovation should not be assumed prima facie as exact, in spite of the Indigenous Innovation Summit's framing.

The below exploration was driven by Indigenous students' perspectives of the Indigenous Innovation Summit. Did the approaches and content of this event resonate with these youth leaders who were eager to harness all available tools to rebuild and revitalize their communities? As a non-Indigenous/settler academic working in the social innovation space, this was an opportunity to critically examine my own pedagogical practice within a larger institutional effort to indigenize campuses and curricula in response to the TRC's calls to action. 
This article will summarize the trends of wise practice in both Indigenous pedagogies and social innovation pedagogy as outlined by established scholars and practitioners; it will then explain common themes derived from the experiences and assessments of Indigenous students themselves at the Indigenous Innovation Summit, an event designed to bring the two concepts together. These themes focused on the value placed on Indigenous cultures and tradition at the summit as sources of social innovation, and also the power, and relative success, of storytelling as a pedagogical medium of meaning making. The themes provide possible areas of commonality of wise practices as potential points to build a trans-systemic bridge, primarily of practice/ontology.

\section{METHODOLOGY}

\section{Interviews}

While several excellent studies have interviewed Indigenous students about their holistic experience or journey through formalized education (Brayboy, 200; Hare \& Pidgeon, 2011; Pidgeon, Archibald, \& Hawkey, 2014), this study focused on understanding the meaning making around a common experience. Semi-structured interviews were performed with all but one of the students who attended the summit as delegates; the last student was unavailable. Nine delegates were selected from a population of approximately 65 self-declared Indigenous students in a business program at a mediumsized Western Canadian university in fall 2015.

Delegates were contacted to arrange interviews approximately five months after the summit; although all expressed an interest, only eight interviews could be completed, six in person and two over email. In-person interviews were recorded and transcribed. Email interviews were offered the same list of questions with optional prompts. All interviewees were offered the opportunity to review and approve their interview transcripts, their quotations, and the eventual manuscript (quotations are presented here as anonymous to protect the students' identities). This was especially important as the interviewer was a non-Indigenous/settler academic, and did not wish to contribute to the long trend of academics appropriating and benefiting from Indigenous knowledges and experiences for professional gain. Textual analysis of these transcripts were analyzed and coded for patterns of meaning making and sense making, specifically efforts to conceptualize and frame their experiences as part of their broader educational experience, which are presented here as themes.

Biographical details have been removed to protect students' anonymity. The interview protocol sought to align itself with the Social Sciences and Humanities Research Council of Canada (SSHRC) guidelines for work with Indigenous communities. Note that this is not the first study to use semi-structured interviews with Indigenous students to explore pedagogical experiments. Cynthia Gallop and Nicole Bastien (2016), for instance, used participant action research (PAR) as one of their methods.

\section{EXPLORING (PARALLEL?) PEDAGOGIES}

\section{Indigenous pedagogies}

Sandra Grande (2008) indicated Indigenous pedagogy is currently more of a project than a completed philosophy or fully articulated and commonly practiced set of approaches. Instead of seeking the colonial (and Sisyphean) task of codifying Indigenous knowledges that are "fluid, nonlinear, and relational" (Kovach, 2015, p. 53) and acknowledging that "a universal Indigenous paradigm does not exist" (Loppie, 2007, p. 276), it is important to learn from the "wise practice" (Voyageur, Brearley, \& Calliou, 2014) of North American Indigenous scholars and practitioners. The section below discusses a few overlapping themes from several Indigenous pedagogical projects/analyses, particularly the emphasis on a holistic approach, place-based and culturally rooted experiential learning, collective/collaborative learning, storytelling, and building engagement. It is not meant to be complete. 


\section{McGowan (2018)}

\section{Holistic approaches}

Erica Neganagwedgin (2011) presents a powerful guiding image: "Traditional ways of learning were wholistic and permeated all aspect so the child" (p. 4). So, when approaching holism in a discussion of Indigenous pedagogies, it is imperative to think about both the knowledge-"all my relations (to seven generations) and the holistic sacredness of Indigenous epistemology" (Sinclair, 2004, pp. 54-56; see also Barnhardt \& Kawagley, 2005)—and the immersion in it/the learning systems (Battiste, 2002; Neganagwedgin, 2011) as it connects to a wider, whole world (Castagno \& Brayboy, 2008). Maxine Matilpi (2012) provides a powerful presentation of Indigenous educational approaches as a wholeness and for wholeness: "[Indigenous] protocols, which express the value of family and community, provide opportunities to recognize, build, and maintain relationships. They continually reaffirm and strengthen our connections and are about building One-ness" (pp. 211-212).

\section{Place-based and experiential learning}

From this whole, immersive perspective, the learner and the learning is rooted in cultural, physical, and historical place and context; it is delivered through immersive experiences (Battiste, 2002, 2013; Grande, 2008; Iseke-Barnes, 2008; Ottman, 2013; Stonechild, 2006).

\section{Collaboration}

Collective, collaborative, and non-competitive learning experiences are important and sought out (Carr-Stewart, Balzer, \& Cottrell, 2013). Coming from an American perspective, Bryan Brayboy (2005) suggests this is a common discussion point of difference between Western and Indigenous ways of knowing, which has significant implications for the classroom, assessment, and overarching pedagogy goals.

\section{Storytelling}

When learning from Indigenous knowledge holders, from elders to family members, storytelling is valued as a key pedagogical tool: "All of this was made understandable through demonstration and observation accompanied by thoughtful stories in which the lessons were embedded" (Barnhardt \& Kawagley, 2005, p. 10). Storytelling can elevate the elder as educator in the "process of reconciliation and resistance," (Iseke \& Brennus, 2011, p. 248); in the classroom it can be used to incorporate Indigenous ways of knowing into that space (MacLean \& Wason-Ellam, 2006). Stories are used to teach values, history, skills (intellectual, practical, and interpersonal), and community integration (Archibald, 2008; Brandhardt \& Kawagley, 2005; Iseke \& Brennus, 2011; Little Bear, 2000; Loppie, 2007; McLean \& Wason-Ellam, 2006).

\section{Engagement}

The purpose of learning and inquiry moves beyond matriculation and toward both life-long learning (Battiste, 2002) and service to the community (Castagno \& Brayboy, 2008; Pidgeon, Archibald, \& Hawkey, 2014). Brayboy's (2005) Tribal Critical Race Theory (TribalCrit) approach necessitates action/activism: "the research must be relevant and address the problems of the community" (p. 440), bringing full circle the notion that the community supports the learner, engages the learner, and the learner engages in the community. There is an iterative relationship between learners and their elders and the community.

So Indigenous pedagogies often encompass an iterative mixture of storytelling, experience/immersion, reflection, and ceremony that brings students together with their peers, their elders, and their community generally. They look inward in reflection and personal (often spiritual) growth and outward for community renewal and relationship (re)building.

Even a cursory awareness of historical Western university pedagogy indicates several discordant notes with Indigenous pedagogies. In particular, the non-linear, non-competitive quality, and the elevation of community, elders, and Indigenous 
knowledge holders over traditionally trained academics and university instructors challenge basic Western assumptions about authority, knowledge flows, and legitimacy within the academy. Both in content and structure, Indigenous pedagogies challenge the stability of ivory towers: "It is apparent that educational organizations have to ask some difficult questions when considering the authentic and meaningful inclusion of Aboriginal peoples" (Ottman, 2013, pp. 10-11).

\section{Figure 2. Indigenous pedagogical wise practice}

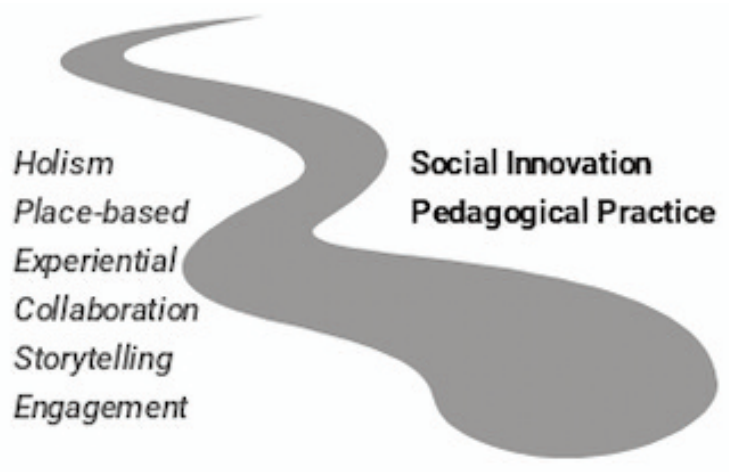

\section{Indigenous Pedagogical \\ Practices}

Figure 2 conceptualizes the above discussion of wise practice on one side of a hypothetical space for a trans-systemic bridge as proposed by Battiste $(2013$, p. 100). It does not presuppose where those intellectual systems might connect to social innovation pedagogy, which is discussed below.

\section{Social innovation pedagogy}

Social innovation-informed education experiences are growing internationally, and "promises of innovative solutions and transformational change seem to be omnipresent" in universities (Moore et al, 2018, p. 47). Social innovation has had a home in the Canadian academy under that name for more than a decade through initiatives such as the McGill-Dupont Social Innovation Think Tank, SiG@Waterloo, the McConnell Foundation's Recode Initiatives (https://re-code.ca/), and engaged (with programming, classes, and space) universities such as Simon Fraser, the University of British Columbia (Sauder School of Business), Ryerson University, Grant McEwan University, Wilfrid Laurier University, and the University of Waterloo, to name a few. Social innovation has a subject of inquiry, a model for educational change (Loogma, TafelViia, \& Ömarik, 2013), and has informed pedagogy (Conrad, 2015; Moore et al, 2018). The former two may look little different from traditional educational environments, and in terms of educational change the social innovation may be in processes students never or rarely see, while the latter remains undertheorized, despite proliferation (Moore et al, 2018). The questions around social innovation curricula and pedagogies are growing: "how do you equip people to address complex problems?" (Cahill \& Spitz, 2017, p. 35).

In their special issue of Academy of Management Learning and Education on the subject, guest editors Thomas Lawrence, Nelson Phillips, and Paul Tracey (2012) suggested that "the impact on how we design courses and course material remains an important challenge" (p. 319). While social innovation and social entrepreneurship are not analogous-although some advocate for a strong connection in education (see Kennan, Canavan, \& Kearns, 2017)-both have, to different extents, grappled with what Dave Roberts and Christine Woods (2005) described as the need to gain legitimacy in academia for what is often practitioner-led or perceived as practitioner-derived. The below discussion suggests these disciplines have shifted classrooms more than be shaped by them. Reflecting on his decades of experience, Gregory Dees 
McGowan (2018)

strongly suggested this kind of innovative, interdisciplinary, even institutional dismantling approach may be necessary to equip students to engage with complex problems (Worsham, 2012).

In their consideration of social entrepreneurship and social innovation education in Canada, Thomas Mengel, Maha Tantawy, and Jeffrey McNally (2016) found a heavy emphasis on experiential learning, trial and error learning, service learning, and practice-based learning in sixty percent of all classes. Additionally, they found the syllabi were a tool for collaboration and cooperation between students and instructors. Chris Steyaert and Daniel Hjorth (2006) argued linking entrepreneurship with social change creates a space where the former moves beyond "economic or progressive-instrument reductionism" (pp. 1-2) and possibly avoids the entrepreneurship field's all-too-frequent race toward unbridled individualism. This is the tension that Yunxia Zhu, David Rooney, and Nelson Phillips (2016) identified in social enterprise programs embedded in management programs and why social entrepreneurs must be trained to balance business with social welfare.

Isaac Smith and Warner Woodworth (2012) emphasize the need for social innovation and entrepreneurship education to instill a social identity that includes the desire to change the world and the belief the student can achieve this change, again through service-learning, active engagement, and out-of-classroom experience(s) (similar to systems leadership, as discussed by Senge, Hamilton, \& Kania, 2015). In their discussion of building "tomorrow's agents of change," Leon Prieto, Simone Phipps, and Tamara Friedrich (2012) emphasized supporting minority students' work in "making a difference in their communities" (pp. 2,6) through a critical social entrepreneurship pedagogy. Results similar to this have been found among students in different populations and pedagogical approaches to social entrepreneurship (Rahim \& Lajin, 2014; Waghid \& Oliver, 2017).

In their examination of the Rockefeller Global Fellows program, which is based on complexity and resilience more than social entrepreneurship, Michele-Lee Moore, Per Olsson, Warren Nilsson, Loretta Rose, and Frances Westley (2018) describe a transformation-oriented pedagogy based on transformation learning theory that deliberately mixed experiential learning, peer coaching, role play, artistic expression, and storytelling in addition to traditional styles of "lecture-knowledge transfer" (p. 41). The pedagogical base of transformational learning (Mezirow, 2000) highlights the program's commitment to reflexivity and self-examination. The use of tools such as design thinking, change labs (Haapasaari, Engestrom, \& Kerosuo, 2016), interdisciplinary teamwork (Conrad, 2015), and community-service learning (Conrad, 2015; Prieto et al, 2012) are common means to achieve experiential education, collaborative spaces, and reflectiveness across studies of social innovation education. Much of this is meant to instill the capacity for/identity of a transformative agent in students.

Transformative learning theory aims at critical reflection through experiences that will encourage students to question their underlying assumptions as they engage with a holistic orientation inclusive of multiple ways of knowing (Alden Rivers, Nie, \& Armellini, 2014; Haapasaari, Engestrom, \& Kerosuo, 2015; Mengel et al., 2016; Russo \& Miller, 2013; Smith \& Woodworth, 2012; Westley, Zimmerman, \& Quinn Patton, 2013). Important here too is a systems lens that encourages students to understand a dynamic context, which they are a part of (Stauch \& Cornelisse, 2016; Weber, 2012; Westley, Zimmerman, \& Patton, 2006). This is balanced by an interest in, and support for, storytelling as a form of sense making and meaning making in complex adaptive systems (Cronon, 1992; Conrad, 2015).

According to Bethany Alden Rivers, Ming Nie, and Alejandro Armellini (2015), social innovation change-makers have six key attributes: "they believe they have a responsibility to make a positive change in society; they have the capacity to make that difference; they take initiative to bring about innovative change that is local and systematic; they work with others in groups and networks; they live "authentically" according to their value; and they practice empathy by engaging in another person's work without judgment" (p. 2). Importantly however, this needs to be rooted in a love for the problem, 
not the solution (Westley, Zimmeran, \& Patton, 2006), or else at least one educator has warned of the risks of "heropreneuers" who think, based on the pedagogical training of pitch competitions and modified business tools, that they-and they alone-can solve the world's problems, and maybe make money at it (Papi-Thornton, 2016).

Based on extant studies (Alden Rivers et al., 2015; Alden Rivers, Nie, \& Armellini, 2014; Conrad, 2015; Mengel et al., 2006; Prieto, Phipps, \& Friedrich, 2012) and a consideration of classes programs, certificates, and competitions surrounding social innovation currently available in Canada, ${ }^{1}$ the following table differentiates these new approaches from more classic university pedagogy.

Table 1: Social innovation education vs. classical education

\begin{tabular}{|c|c|}
\hline Social innovation classes & Classical classes \\
\hline Experiential/situational & Experiential or scholastic/lecture \\
\hline Collaborative & Individual \\
\hline Reflective \& contextual ${ }^{2}$ & Linear $^{3}$ \\
\hline Love the problem/system-focused & Solution/results focused \\
\hline Transformation learning & $\mathrm{N} / \mathrm{A}$ \\
\hline
\end{tabular}

Figure 3: Social innovation pedagogical practice

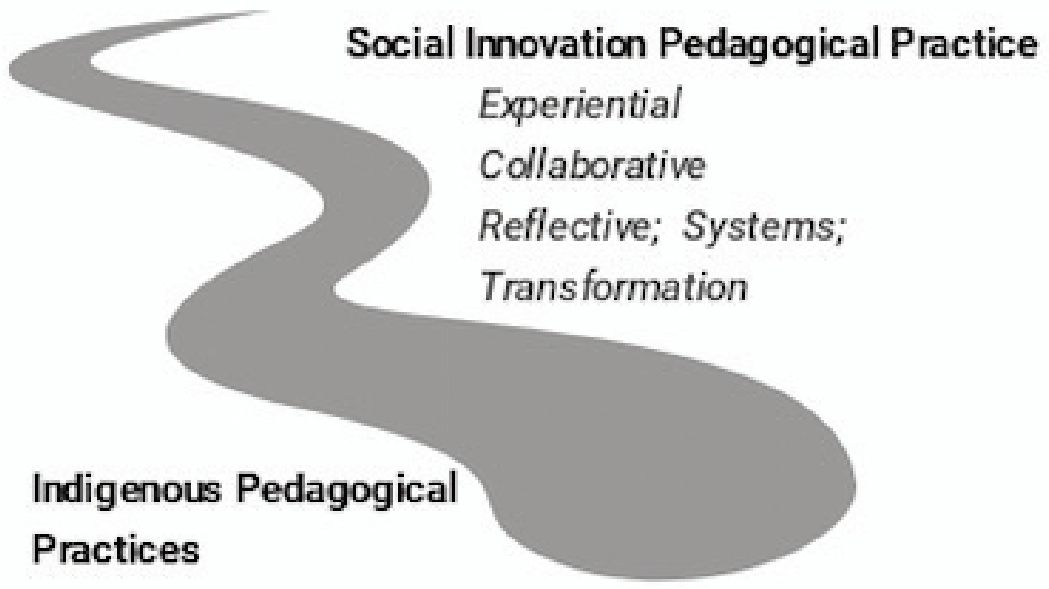

Similar to Figure 2, Figure 3 conceptualizes elements of social innovation pedagogy on one side of a hypothetical transsystemic bridge. This article will now explore both the Indigenous Innovation Summit and students' meaning making to explore possibilities for a bridge that empowers Indigenous students.

\section{Indigenous Innovation Summit: Content and approach}

There is no part of Canada that bears less of a responsibility for reconciliation; there is no one city that is unconcerned with Indigenous issues. However, Winnipeg often looms large in conversations about Indigenous issues in Canada because of the city's large visible Indigenous population, especially in its notorious North End; a series of terrible, avoidable deaths in the city drew national media attention and resulted in one publication declaring Winnipeg as the place "where Canada's racism problem is at its worst" (MacDonald, 2015). It was in this context that 320 people gathered in November 2015 at the Winnipeg Art Gallery to talk about Indigenous social innovation (MacDonald, 2015). 


\section{McGowan (2018)}

The summit's primary leadership came from the National Association of Friendship Centres, an association of 118 urban Indigenous service delivery centres across Canada (especially important as between 50 and 60 percent of Canada's Indigenous population lives in urban centres) (MacDonald, 2015). For two-and-a-half days (cold and wintry ones-a prairie winter storm landed during the opening night reception) academics, business leaders, elders, artists, and students met to connect over discussions and explorations of social innovations—current and possible_among Canada's Indigenous communities. They explored how these conservations could build those communities' resilience on the one hand and foster reconciliation between Indigenous and non-Indigenous Canadians on the other in order to build relationships and "a field of understanding" (CBC, 2015).

Summit organizers sought explicitly to engage participants. As National Association of Friendship Centres' executive director Jeffrey Cyr explained to the Canadian Broadcasting Company (CBC, 2015), "It's not a typical summit ... we actually get engaged, its interaction and people work together on things." The summit used interactive storytelling as a key presentation form to both large and small groups; it also used drum circles, singing and dancing performances, elders' talks, ceremony, a world café focused on reconciliation journeys, and a change lab as part of its program. Additionally, sessions were categorized to aid participants, ranging from introductory (focused on storytelling successes) to intermediate (more interactive) to advanced (usually with a heavy amount of coaching). Topics included social innovation generally, social finance, innovation in education, youth innovation, healthcare, reconciliation and intergenerational reconciliation, and many examples of Indigenous initiatives and leaders-emergent and established. There were strong experiential elements, but given the emergent state of our understanding of Indigenous social innovation in those terms and the brevity of the summit (two-and-a-half days), the greater emphasis was storytelling.

\section{INDIGENOUS STUDENT INTERVIEWS}

Before comparing the wise practices for points of possible commonality, it is useful to consider what the students took away from the summit. It is important to note that social innovation itself, while generally of interest to the students both before and after the summit, did not become clearer or more coherent for them through the process, which underlines that their experiences cannot simply be used as validation for the existence of a trans-systemic bridge (Battiste, 2013, p. 100) but as triangulation of its potential as an empowering space for Indigenous students and broader institutional decolonization and indigenization. Ergo, each theme will be discussed independently and then compared to wise practices for potential commonality.

\section{Theme one: A bridge between culture and innovation}

If the summit was meant to build a field of understanding between social innovation and Indigenous communities and individuals, the students more clearly identified with the Indigenous element than the social innovation field generally. Indeed, when asked how they defined social innovation before and after the summit, no one student replied the same way, with answers ranging from new solutions to old problems to life-long learning. At least two students said the concept became more ambiguous to them through the summit.

Alternatively, the value of seeing and meeting Indigenous entrepreneurs and leaders was clear and universally held. Consider the following reflection from one student on Indigenous entrepreneurs (without necessarily the "social" qualifier): "The Summit seemed like an amazing opportunity to talk about the heritage of Indigenous entrepreneurs in Canada and forecast the future of these successful business peoples." Another student emphasized the importance of moving away from dependency on the federal government through business and entrepreneurship: "We could come back to doing things for ourselves and making ... a profit so that we could help ourselves and also do good, you know without having to rely on ... the government." One student expressed a new, less cynical view of social enterprise: "It seemed like social 


\section{McGowan (2018)}

enterprise to me now seems like it's in the middle of the two, like you are able to make profits and give a lot back to the community as opposed to like giving a little bit in order to make yourself look good."

The students' recognition and interest that Indigenous cultures could be the source of innovation led to the most fertile cross-discussion of social innovation and indigenity. According to the students, presenters at the summit "used their culture to kind of show the world that aboriginals can like do things and ... they create beautiful things with it." One student in particular hit on the idea that culture could be the origin of meaningful innovations:

What really interested me at the summit was how everyone's innovation involved integrating their cultural roots to propose simpler solutions. It is easy to believe that complex problems will require a complex approach, however the ability to execute simplicity, while honouring cultural traditions was demonstrated to be an effective way to address these issues.

One student took this further and reflected on possibly being a social innovator: "I've followed lots of traditional stuff and it's always just, you know, the new way of doing things was school ... my way of being an innovator was getting out there." Similarly, as part of intergenerational cultural/national revival: "I really enjoyed how they had so many great people, elders and young people that were all just wanting, wanting to try and [be] innovative and find new ways and a new future for Indigenous people."

All the student delegates were business students. A business degree was a choice: many of the students described a history (and/or family history/family influence) of business or entrepreneurship, most strongly identified the practicality/applicability of their degree as a tool to achieve broader goals as a major driver in their choice of studies. Therefore, it is not perhaps surprising that none of them verbalized a concern with the business-orientation of social innovation/entrepreneurship, as other observers have done (Mengel et al., 2016; Weber, 2012)_although this is speculation.

Five of the interviewees explicitly discussed how the summit helped them bridge the space between their culture, hopes for community, and their business education: "I love business and I love my culture but it was hard to see how they would work together, um, and with ... the Summit I was kind of able to learn a little bit more about how they could work together." Similarly: "elders saying ... you need to learn your traditional ways and combine them with the western ways and I think that's the main point of what I got out of the Summit." At the very least, this would suggest the summit offered a space to bridge Indigenous culture and business education, something students had not found in traditional education, which unfortunately has a virtual "culture of silence" (Sinclair, 2004, p. 52) on Indigenous business.

All but one interviewee referenced (without prompting) the Moose Hide Campaign (McDonald, 2015). It is not surprising the Moose Hide Campaign stuck with the students for months: a father and daughter-Paul and Raven Lacerte-still grieving the loss of a wife and mother, spoke (and then sang and drummed in ceremony) about their campaign to end violence against Indigenous women. Supporters wear a small square of hide on their label to demonstrate that they are open to talking about violence in their communities and their commitment to not use violence in their daily lives. Raven caught the first moose for the campaign along the Highway of Tears in British Columbia (a notorious stretch of road where many people, including many Indigenous women, have disappeared), in a gesture "meant to be a conversation started about how we value and treat Aboriginal women in our country and ultimately a way to end the violence" (National Association of Friendship Centres, 2015, p. 7).

While some students simply said the presentation either stuck with them or affected them, one student in particular reflected on its connection with conversations about innovation: "through this experience I have thought a lot more about 


\section{McGowan (2018)}

the power of innovation, and how if used in the right way you can empower people to influence change. ... I love the fact that I still keep seeing the moose hide pin's [relevance] several months after the summit." The power of a great idea, even one small in implementation, can trigger a shift in approach—and potentially a shift in a wider system.

\section{Theme two: The power of stories}

The summit emphasized the use of storytelling to convey both the narrative of Indigenous-directed change efforts, as well as the values of social innovation and cultural/national revival. These stories were meant to resonate on an emotional and intellectual level, very much in keeping with how Metis elder Tom McCallum discussed storytelling as pedagogy:

We include a lot of things in storytelling that we leave for the other person to be able to interpret themselves. It gets the mind going. It puts their experiences together and validates them as a person who has the ability to be able to draw from that storytelling and relate it to their own lives. (Tom McCallum cited in Iseke \& Brennus, 2011, p. 250)

There are several important elements here: a story's capacity to inspire personal reflection, to build a connection between learning and everyday life, and to inspire action and/or further learning. How did the student delegates feel about the use and form of stories at the summit?

Every interviewee spoke to some degree about the emotional resonance of the summit storytellers. They used the following terms to describe the stories and storytelling at the event: inspiring/inspirational (4); powerful (4); engaged/engaging (3); passion/passionate (3); emotional (3); heartwarming (1); resonated (1); blew me away (1); humanized (1); empowering (1); relevant (1); and enlightening (1). Several students effectively captured the possibility of transformation from the stories (again, without interviewer prompting):

"They [the speakers] brought that traditional part, life lessons, learning life lessons, not learning from a book, living life."

"... it's not until later on when you apply it to real life solutions that you realize you learned something."

"I still think of some of the stories now."

"[Acting as a storyteller themselves] Some people listened there because it was something real ..."

"most of our stories, not just my families but Indigenous stories were never written down, they were always spoken and they always have some lessons behind them ... I don't think they meant us to follow the exact process that they did, they kind of were trying to say, like here's our story, this is what came out of it and you need to kind of like find your own path. ... So I've heard how I now apply that to my life, or how do I take that story and make my own way to make it happen."

\section{DISCUSSION}

There is a risk when discussing Indigenous pedagogies in relation to other ways of knowing and teaching that the former is either elevated to the untouchable sacred (Battiste, 2002), or sliced up and slotted into a non-Indigenous context, disregarding the different origin knowledge/ways of knowing. Even seemingly useful cross-cultural approaches may be insufficient if they do not address Indigenous history and knowledges: "the danger lies in proclaiming an anti-oppressive stance, while doing little or nothing to address the reality of oppression" (Sinclair, 2004, p. 52). Indeed, some have invested 
significant thought into metrics of brokering Indigenous and non-Indigenous epistemologies (Kitchen, Cherubini, Trudeau, \& Hodson, 2009; Ottman, 2013). In order to be sensitive to both concerns, it is important not to look for where Indigenous content and concepts "might fit" in a social innovation context, but instead look for points of epistemological sympathy for a trans-systemic bridge.

Figure 4: Points of triangulation

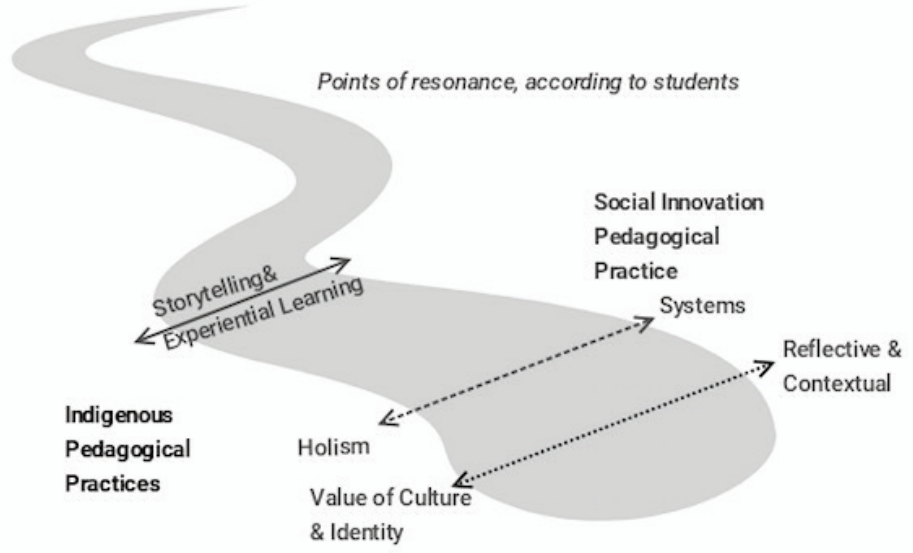

Figure 4 represents the triangulation of students' themes with the two pedagogical wise practices. Based on their own accounts, storytelling and experiential learning seem the strongest points of resonance/common meaning for the students followed by an interest in systems and holism; the strong value they placed on seeing their cultures as sources of innovation is not necessarily reflected in general social innovation education but may be considered proximate to the value on context and reflection. The latter two are discussed below in more detail.

\section{Storytelling}

When students talked about the summit storytelling, it was frequently in those terms, as an opportunity to connect with others and their community, but also to reflect internally on what that story did or could mean to them. These stories, and the emotional/intellectual questions they inspired, stayed with students for the five long months between summit and interview. Here is the strongest suggestion of sympathy between Indigenous pedagogy and social innovation pedagogy, where emotion and intellect, reflection and connection come together in the iterative act of storytelling.

\section{Context and reflection}

It is illuminating that students went into their business degree with some degree of passion, either for business directly or to do something for their community, but found little space for action or their culture in their traditional business education. As one student reflected, "I would say its something that's not talked about." Yet most found at the summit that passion for what businesses can achieve. Consider the following: "they [the speakers] had the same passion of just trying to help people, and I think most people forget about that when they get into business." Students' passion for enterprise and business was not necessarily one for personal aggrandizement; many explicitly talked about what they wanted to do for their families, to take a leadership role, to work for their communities, which is consistent with other studies of Indigenous students (Brayboy, 2005; Hare \& Pidgeon, 2011). They found this drive reflected back at them at the summit-a form of reflective learning of great value.

That Indigenous cultures were so often the source of those solutions discussed at the summit excited and inspired the students, which suggests the need for a broad, community-informed approach when integrating Indigenous issues and social innovation; a greater awareness of the systems in which students are embedded. This is not surprising, but it places 


\section{McGowan (2018)}

a burden on instructors to seek out elders and respected community members to inform and enrich that process. Giving up the power of the lectern may be a necessary sacrifice of educators seeking the foundation for a trans-systemic bridge.

\section{Caution ahead}

The sympathies between social innovation pedagogy (as currently imagined) and Indigenous pedagogies are not perfect. The focus in some social entrepreneurship programs on the individual agent in many examples of the former is too narrow, with the risk of losing their inherent embeddedness and interconnectedness with the community, the ecosystem and history, more common in systems-informed programs. There is a tension between individual initiative and community consent here that needs to be (and is yet not) resolved; Daniela Papi-Thornton's (2016) discussion of "heropreneurship" (ssir.org) illustrates an awareness of this, as does the criticism of some of the focus on change agents (Stedman, 2016) found in established social innovation literature (Moore \& Westley, 2011: Westley et al., 2011).

Interestingly, the idea of simply inserting more Indigenous content into classes or a required class met with lukewarm support among student interviewees. While some studies suggest maintaining a "strong cultural identity" (Gallup \& Bastien, 2016, p. 211) is key to avoiding the sense of assimilation, supporting that intellectual space may be partially about building empathy rather than just adding content without context. Student interviewees called for a better understanding of the kinds of problems and challenges they would face once out of school and that others had faced, and real-world solutions that engaged and involved students. Here is where we see an organic or emergent call for educational "tools and methods that support the design of high impact solutions" (Russo \& Miller, 2013, p. 175), which were identified earlier as characterizing much of social innovation education. And here it is important to come back to the purpose of Indigenizing the Canadian university curricula, as Jacqueline Ottman (2013) points out: "As we reflect upon what it means to 'Indigenize the academy,' we are beginning from the presumption that the academy is worth Indigenizing because something productive will happen as a consequence" (p. 11). From the students' perspective, the linking of social innovation and Indigenous culture was a productive, inspiring space. It may not quite be the productive space Ottman imagined but it is certainly very promising.

It is important to reiterate that these students are not representative, and therefore they are not a test of what meets the standards of Indigenous education-indeed no one group of Indigenous educators or students is so equipped. Instead, we can understand how inspired these students felt to see a space for Indigenous communities in the social innovation world, and a space for innovation and innovative approaches to challenges in those communities. Importantly, this was seen as innovating from a position of strength—-their cultural tradition-despite the deep, structural issues those communities face.

The relationship between social innovation and Indigenous communities may be nascent, and so too the educational toolkits associated with those concepts. However, the excitement and inspiration these students experienced in an immersive, culturally relevant event is a promising notice for social innovation and Indigenous business educators looking for a strong foundation for a trans-systemic bridge. Students themselves found this bridge between their passion and their practicality, between business and indigenity, between innovating and rejuvenating. We should follow their lead.

\section{CONCLUSION}

One student indicated the need for coming together between Indigenous and non-Indigenous Canadians: "I think it's really important for Indigenous and non-Indigenous people to come to a common ground and learn about each other. ... When we say everyone's invited, we mean it, it's open arms and its reconciliation." Whether that sentiment reflects the summit generally or a possible sympathy for a systemic bridge is still open for debate, but these early signs are promising. 


\section{McGowan (2018)}

There seem to be a few practices both in social innovation education and Indigenous pedagogies that would point to sympathetic philosophical roots between the two. The summit itself seemed to act as a bridge between culture and tradition on the one hand and innovation on the other (theme one) and the students' reflections on stories (theme two) is consistent with how storytelling as pedagogy is emerging broadly as a powerful tool for self-reflection and social change outside of (but not regardless of) and Indigenous context (Coulter, Michael, \& Poynor, 2007).

Importantly though, all future explorations must be done with humility and in partnership; to Indigenize social innovation education or any other field of instruction without strong and empowered Indigenous partnership would be to fail before we begin. Social innovation educators must (and are starting to) build strong relationships and the license of active and engaged consent from Indigenous communities_and hopefully iterative horizontal partnership. This is more than empathy, it is the humility of an actor enabled to act and doing so in relation to place, history, and community. "Everyone's invited" is not an invitation to replace colonization with social innovation, but to discover new ways to work together-in the classroom as well as in the world.

\section{NOTES}

1. This included Mount Royal University's (MRU): Agents of Social Change (community service learning project, based on social innovation lab methodology); Social Enterprising (launching cooperatives); Facilitation for Social Innovation (working in groups directly with a community client); Introduction to Social Innovation (particularly its social innovation lab). UW: Graduate Diploma in Social Innovation; Banff Residency in Social Innovation (with the Banff Centre). Ryerson: ENT 56A/B describes class content, including social innovation as very experiential and transformative; working in groups with the Toronto entrepreneurial ecosystem to launch an enterprise or social innovation. SFU: Social innovation competition. McGill: MGPO 438 Social Entrepreneur \& Innovation (Nowak, 2015) (this last class seems the closest to classic business/nonprofit education).

2. Reflective means that no one piece of the experience is more important than another; while they are related to each other and can build on each other, breakthroughs and learning are more contingent on how the group interacts with the material. Importantly, the experience(s) a student brings to the group are key to instruction.

3. Linear refers to lectures building effectively on each other; material has an additive benefit and results can be compared across students (relatively) regardless of their pre-class knowledge.

\section{REFERENCES}

Alden Rivers, B., Armellinin, A., Maxwell, R., Allen, S., \& Durkin, C. (2015). Social Innovation education: Towards a framework for learning design. Higher Education, Skills \& Work-based Learning, 5(4), 383-400.

Alden Rivers, B., Nie, M., \& Armellini, A. (2014). University teachers' conceptions of 'changemakers': A starting point for embedding social innovation in learning and teaching. Education + Training, 57(5), 588-600.

Alexiuk, E. (2013). Exploring the common ground between social innovation and Indigenous resurgence: Two critical indigenist case studies in Indigenous innovation in Ontario, Canada [Master's thesis]. Waterloo, ON: University of Waterloo.

Anderson, R., Paul Dana, L., \& Dana, T. (2006, February). Indigenous land rights, entrepreneurship, and economic development in Canada: Opting-in to the global economy. Journal of World Business, 41(4), 45-55.

Anderson, B., Honig, B., \& Peredo, A. (2012). Communities in the global economy: Where social and indigenous entrepreneurship meet. In T. Burger-Helmchen (Ed.), Entrepreneurship: Gender, Geographies \& Social Context (pp. 56-78). Rijeka, HR: InTech.

Archibald, J. (2008). Indigenous storywork: Educating the heart, mind, body, and spirit. Vancouver, BC: UBC Press. Battiste, M. (2013). Decolonization education: Nurturing the learning spirit. Saskatoon, SK: Purich. 
Battiste, M. (2002, October 31). Indigenous knowledge and pedagogy in First Nations education: A literature review with recommendations prepared for the National Working Group on Education and the Minister of Indian Affairs, INAC. Ottawa, ON: INAC.

Barnard, D. (2015, June 8). The role of Canadian Universities in reconciliation. Universities Canada. URL: https:// www.univcan.ca/media-room/media-releases/david-t-barnard-the-role-of-canadas-universities-in-reconciliation/ [March 8, 2018].

Barnhardt, R., \& Kawagley, A.O. (2005). Indigenous knowledge systems and Alaska native ways of knowing. Anthropology \& Education Quarterly, 36(1), 8-23.

Brayboy, B.M.J. (2005). Toward a tribal critical race theory in education. The Urban Review, 37(3), 425-446.

Cahill, G., \& Spitz, K. (2017). Social innovation generation: Fostering a Canadian ecosystem for systems change. Montréal, QC: J.W. McConnell Family Foundation.

Carr-Stewart, S., Balzer, G., \& Cottrell, M. (2013). First Nations post-secondary education in Western Canada: Obligations, barriers, \& opportunities. In K. Anderson \& M. Hanrahan (Eds.), The Morning Watch: Education and Social Analysis Special Issue: Indigenizing the Academy 40(3-4), 25-34.

Castagno, A., \& Brayboy, B.M.J. (2008). Culturally responsive schooling for Indigenous youth: A review of the literature. Review of Educational Research, 78(4), 941-993.

CBC News. (2015, November 19). Indigenous Innovation Summit puts positive spin on social change. CBC News Manitoba. URL: http://www.cbc.ca/news/canada/manitoba/indigenous-innovation-summit-puts-positive-spin-on -social-change-1.3325981 [June 19, 2016].

Conrad, D. (2005). Education and social innovation: The youth uncensored project - A case study of youth participatory research and cultural democracy in action. Canadian Journal of Education, 38(1), 1-25.

Coulter, C., Michael, C., \& Poynor, L. (2007). Storytelling as pedagogy: An unexpected outcome of narrative inquiry. Curriculum Inquiry, 37(2), 103-122.

Cronon, W. (1992). A Place for Stories: Nature, History and Narrative. The Journal of American History 78(4): 1347-1376.

Fernando, M. (2011). A social innovation based transformative learning approach to teaching business ethics. Journal of Business Ethics Education, 8(2-11), 119-138.

Gallop, C., \& Bastien, N. (2016). Supporting success: Aboriginal students in higher education. Canadian Journal of Higher Education, 46(2), 206-224.

Goldenberg, M., Kamoji, W., Orton, L., \& Williamson, M. (2009). Social innovation in Canada: An update. Ottawa, ON: Canadian Policy Research Networks.

Grande, S. (2008). Red pedagogy: The un-methodology. In N.K. Denzin \& Y. Lincoln (Eds), Handbook of Critical and Indigenous Methodologies (pp. 233-254). Thousand Oaks, CA: Sage Publication.

Haapasaari, A., Engestrom, Y., \& Kerosuo, H. (2016). The emergence of learners' transformative agency in a Change Laboratory Intervention. Journal of Education and Work, 29(2), 232-262.

Hare, J., \& Pidgeon, M. (2011). The way of the warrior: Indigenous youth navigating the challenges of schooling. Canadian Journal of Education//Revue canadienne de l'education, 34(2), 93-111.

Hindle, K., Anderson, R., Giberson, R., \& Kayseas, B. (2005, Winter/Spring). Relating practice to theory in Indigenous entrepreneurship: A pilot investigation of the Kitsaki Partnership Portfolio. American Indian Quarterly, 29(1\&2), 1-23.

Hindle, K., \& Moroz, P. (2010). Indigenous entrepreneurship as a research field: Developing a definitional framework from the emerging canon. International Enterprise Management Journal, 6(4), 357-385.

Howorty, C., Smith, S., \& Parkinson, C. (2012). Social learning and social entrepreneurship education. Academy of Management Learning \& Education, 11(3), 371-389.

Hurley, M., \& Wherrett, J. (1999, October 4). The report of the royal commission on Aboriginal Peoples. Ottawa, ON: Government of Canada. URL: http://www.lop.parl.gc.ca/content/lop/researchpublications/prb9924-e.htm [March 31, 2017]. 


\section{McGowan (2018)}

J.W. McConnell Family Foundation. (2017). Resources for schools: Building social infrastructure. https://re-code.ca/

8 September 2017 [January 11, 2019].

Iseke-Barnes, J. (2008). Pedagogies for decolonization. Canadian Journal of Native Education, 31(1), 123-147.

Iseke, J., \& Brennus, B.M.J.K. (2011). Learning life lessons from Indigenous storytelling with Tom McCallum. In G.S.

Dei (Ed), Indigenous philosophies and critical education: A reader (pp. 245-261). New York, NY: Peter Long.

Kennan, D., Canavan, J., \& Kearns, N. (2017). Fostering social innovation in youth: Learning from a youth social entrepreneurship initiative in Ireland. In S. Bastien \& H. Holmasdottir (Eds) Youth as architects of social change (pp. 277-300). Basingstoke, UK: Palgrave Macmillan.

Kitchen, J. Cherubini, L., Trudeau, L., \& Hodson, J. (2009). Aboriginal education as cultural brokerage: New Aboriginal teachers reflect on language and culture in the classroom. McGill Journal of Education, 44(3), 355-375.

Kovach, M. (2015). Emerging from the margins: Indigenous methodologies. In L. Brown \& S. Strega (Ed), Research as resistance: Revisiting critical, Indigenous, and anti-oppressive approaches (pp. 43-64) Toronto, ON: Canadian Scholar's Press.

Lawrence, T., Phillips, N., \& Tracy, P. (2012). From the guest editors: Education social entrepreneurs and social innovators. Academy of Management Learning and Education, 11(3), 319-323.

Little Bear, L. (2000). Jagged worldviews colliding. In M. Battiste (Ed), Reclaiming indigenous voice and vision (pp. 75-85). Vancouver, BC: University of British Columbia Press.

Loppie, C. (2007). Learning from the grandmothers: Incorporating Indigenous principles into qualitative research. Qualitative Health Research, 17(2), 276-284.

Loogma, K., Tafel-Viia, K., \& Ümarik, M. (2013). Conceptualizing educational changes: A social innovation approach. Journal of Educational Change, 14(3), 283-301.

MacDonald, N. (2015, January 22). Welcome to Winnipeg: Where Canada's racism problem is at its worst. McClean's Magazine, https://www.macleans.ca [March 31, 2017].

MacLean, M., \& Wason-Ellam, L. (2006). When Aboriginal and Métis teachers use storytelling as an instructional practice. Saskatchewan: Aboriginal Education Research Network.

Matilpi, M. (2012). In our collectivity: Teaching, learning and Indigenous voice. Canadian Journal of Native Education, $35(1), 211-223$.

McCarthy, D.D.P, Millen, M., Boyden, M., Alexiuk, E., Whitelaw, G.S., Viswanathan, L., Larkman, D., Rowe, G., \& Westley, F.R. (2014). A First Nations-led social innovation: A moose, a gold mining company, and a policy window. Ecology and Society, 19(4), article 2

McDonald, N. (2015, December 16). Indigenous innovation summit: What happened and what's next?" [blog post]. Montréal, QC: J.W. McConnell Family Foundation. URL: http://www.mcconnellfoundation.ca/blog/2015/12/16/ [March 31, 2017].

McNalley, M. (2004). Indigenous pedagogy in the classroom. American Indian Quarterly, 28(3-4), 604-617.

Mengel, T., Tantawy, M., \& McNally, J. (2016, April). Social entrepreneurship education in Canada: Passion \& practice. Workplace Review 1, 57-70.

Mezirow, J. (2000). Learning as transformation: Critical perspectives on a theory in progress. San Francisco, CA: Jossey-Bass Higher \& Adult Education Series.

Moore, M-L., \& Westley, F. (2011). Surmountable chasms: Networks and social innovation for resilient systems. Ecology and Society, 16(1), article 5.

Moore, M. L., Olsson, P., Nilsson, W., Rose, L., \& Westley, F. (2018). Navigating emergence and system reflexivity as key transformative capacities: experiences from a Global Fellowship program. Ecology and Society, 23(2), 38-53.

National Association of Friendship Centres. (2016). Indigenous Innovation Summit report, 2015. Ottawa, ON: National Association of Friendship Centers. 
Neganagwedgin, E. (2011). A critical review of Aboriginal education in Canada: Eurocentric dominance impact and everyday denial. Aboriginal Policy Research Consortium International (APRCi), paper 440.

Nicholl, A. (2011). The Nature of Social Innovation. In A. Nichol \& A. Murdock (Eds), Social innovation: Blurring boundaries to reconfigure markets (pp. 1-30). London, UK: Palgrave.

Nowak, A. (2015). MGPO 438 Social Entrepreneurship and Innovation (3 credits), Desaults Faculty of Management. Course Calendar. Montréal: McGill University http://www.mcgill.ca/study/2015-2016/courses/MGPO-438 [January 11, 2019]

Ottman, J. (2013). Indigenizing the academy: Confronting 'contentious ground.' In K. Anderson \& M. Hanrahan (Eds.), The morning watch: Education and social analysis. Special Issue: Indigenizing the Academy 40(3-4), 8-25.

Papi-Thornton, D. (2016). Tackling heropreneurship. Oxford, UK: Skoll Centre for Social Entrepreneurship-University of Oxford, Clore Social Leadership Programme.

Pidgeon, M., Archibald, J., \& Hawkey, C. (2014). Relationships matter: Supporting Aboriginal graduate students in British Columbia, Canada. The Canadian Journal of Higher Education, 44(1), 1-21.

Pol, E., \& Ville, S. (2009). Social innovation: Buzz word or enduring term? The Journal of Socio-Economics, 38(6), 878-885.

Prieto, L., Phipps, S., \& Friedrich, T. (2012). Social entrepreneur development: An integration of critical pedagogy, the theory of planned behaviour and the ACS model. Academy of Entrepreneurship Journal, 18(2), 1-15.

Rahim, H.L., \& Lajin, N.F.M. (2015). Social entrepreneurship and graduate employability. International Academic Research Journal of Social Science, 1(1), 33-40.

Roberts, D., \& Woods, C. (2005). Changing the world on a shoestring: The concept of social entrepreneurship. University of Auckland Business Review 7(1): 45-51.

Russo, P., \& Miller, S. (2013). Social innovation education. In T. Osburg \& R. Schmidpeter (Eds.), Social innovation: Solutions for a sustainable future (pp. 171-181). Heidelberg, DE: Springer.

Senge, P., Hamilton, H., \& Kania, J. (2015, Winter). The dawn of systems leadership. Stanford Social Innovation Review 13(1), 27-33.

Sinclair, R. (2004, September). Aboriginal social work education in Canada: Decolonization pedagogy for the seventh generation. First Peoples Child and Family Review, 1(1), 49-61.

Smith, I., \& Woodworth, W. (2012). Developing social entrepreneurs \& social innovators: A social identity and selfefficacy approach. Academy of Management: Learning \& Education, 11(3), 390-407.

Stauch, J., \& Cornelisse, L. (2016). Strengthening community leadership learning in Canada: Results of a Canadawide research project on leadership learning for social change [Report]. The Institute for Community Prosperity. Calgary, AB: Mount Royal University.

Stedman, R. (2016). Subjectivity and social-ecological systems: A rigidity trap (and sense of place as a way out). Sustainability Science, 11(6), 891-901.

Steyaert, C., \& Hjorth, D. (2006). Introduction: What is social entrepreneurship?" In C. Steyaert \& D. Hjorth (Eds.), Entrepreneurship as social change: A third movement in entrepreneurship book (pp. 1-18). Cheltenham, UK: Edward Elgar.

Stonechild, B. (2006). The new buffalo: The struggle for Aboriginal post-secondary education in Canada. Winnipeg, MB: University of Manitoba Press.

Truth and Reconciliation Commission of Canada. (2015). Truth and Reconciliation Commission of Canada: Calls to action. Winnipeg, MB: Truth and Reconciliation Commission of Canada. URL: trc.ca [March 31, 2017]

Tapsell, P., \& Woods, C. (2010). Social entrepreneurship and innovation: Self-organization in an Indigenous context. Entrepreneurship and Regional Development, 22(6), 535-556.

Volynets, I. (2015). Social innovation and Aboriginal communities. Prepared for Urban Aboriginal Knowledge Network, National Secretariat. 
McGowan (2018)

Voyageur, C., Brearley, L., \& Calliou, B. (Eds.). (2014). Restoring Indigenous leadership: Wise practice in community development (2nd ed.). Banff, AB: Banff Centre Press.

Waghid, Z., \& Oliver, H. (2017). Cultivating social entrepreneurial capacities in students through film: Implications for social entrepreneurship education. Educational Research for Social Change, 6(2), 76-100.

Weber, J.M. (2012). Social innovation and social enterprise in the classroom: Frances Westley on bringing clarity and rigor to program design. Academy of Management: Learning \& Education, 11(3), 409-418.

Westley, F., Zimmerman, B., \& Quinn Patton, M. (2006). Getting to maybe: How the world is changed. Toronto, ON: Random House.

Westley, F., Tjornbo, O., Schultz, L., Olsson, P., Folke, C., Crona, B., \& Bodin, O. (2013). Transformative agency in linked social-ecological systems. Ecology \& Society, 18(3), article 27.

Worsham, E.L. (2012). Reflections and insights on teaching social entrepreneurship: An interview with Greg Dees. Academy of Management Learning \& Education, 11(3), 442-452.

Zhu, Y., Rooney, D., \& Phillips, N. (2016). Practice-based wisdom theory for integrating institutional logics: A new model for social entrepreneurship learning and education. Academy of Management Learning \& Education, 15(3), $607-625$.

\section{ABOUT THE AUTHOR / L'AUTEUR}

Katharine McGowan is an Assistant Professor of Social Innovation at in Mount Royal University. Her research areas include historical social innovation and resilience. Email: kmcgowan@mtroyal.ca . 